ISSN 1991- 8690

الترقيم الدولي •1991 - 199

website: http://jsci.utq.edu.iq

Email: utjsci@utq.edu.iq

\title{
Inhibition of Carbon Steel Acid Corrosion Using Vanillin
}

\author{
Adnan S.AbdulNabi \\ Luma T.Tomaa \\ Ihsan A. Mikshif \\ Department of Chemistry - College of Education - University of Basrah
}

\begin{abstract}
The inhibition action of the corrosion of carbon steel in hydrochloric acid solution by vanillin has been studied using weight loss technique. Inhibition was found to increase with increasing inhibitor concentration and decreasing temperature. A first order mechanism has been deduced from the kinetic treatment of the weight loss results and the process of inhibition was attributed to physiosorption. The results obtained showed that vanillin could serve as an effective inhibitor of the corrosion of carbon steel in hydrochloric acid media.
\end{abstract}

Key words: corrosion inhibition, carbon steel, hydrochloric acid, vanillin, weight loss. 


\section{Introduction:}

Carbon steel is widely used in various industries as a structural materials. Its exposure to aggressive environments like concentrated acids, alkalis, salt solutions,....etc. leads to its degradation. Considerable quantities of corrosion loss of steel occurs in acid medium and inhibitors for carbon steel corrosion find importance among other corrosive media ${ }^{(1)}$. Acid inhibitors have wide applications in the industrial field as a component in pretreatment composition, in cleaning solution for industrial equipments and in acidization of oil wells and in petrochemical plants ${ }^{(2)}$. It was found that, the organic compounds are effective corrosion inhibitors due to their ability to form an adsorbed film on the metal surface. Many organic compounds are used as corrosion inhibitors in acidic environments in various industries ${ }^{(3,4)}$. The adsorption of carbonyl compounds on the metal surface was shown to occur through their carbonyl groups ${ }^{(5)}$. Vanillin is an aromatic aldehyde that possess a pleasant fragrance. Vanillin is the key component in vanilla flavoring and can be found in perfumes and other scented products, as well. Very little information is known about the use of vanillin as corrosion inhibitor for metals. The objective of the present work is to study the inhibitive action of vanillin toward the corrosion of carbon steel in $0.5 \mathrm{M}$ hydrochloric acid solution. Weight loss measurement was used to evaluate the inhibition efficiency of vanillin.

\section{Experimental:}

For the weight loss measurements, carbon steel sheets $(7.2 \times 2.2 \times 0.3 \mathrm{~cm})$ of chemical composition, $0.25 \% \mathrm{C}, 0.73 \% \mathrm{Mn}, 0.18 \% \mathrm{Si}, 0.028 \% \mathrm{~S}, 0.01 \% \mathrm{P}$, and the reminder iron were used. The samples were polished with different grade emery papers, cleaned with acetone, washed with double distilled water and finally dried and kept in desiccators ${ }^{(6)}$. Each coupons were suspended by a glass hook and immersed in $200 \mathrm{ml}$. beakers containing $0.5 \mathrm{~N}$ HCI solution (Blank) and with additive concentration of $(100,200,300,400$ and $500 \mathrm{ppm})$ in $0.5 \mathrm{~N}$ HCI solution at 30,40 and $50^{\circ} \mathrm{C}$ respectively. The specimens weight are measured by electronic balance ( Sartoius BL 210S ) and then suspended inside the solution. After $2 \mathrm{hr}$. in the solution, the specimens were raised from the solution, washed in tap water in order to remove all the corrosion products from the metal surface, washed again with distilled water, dried by clean tissue and then the specimens were weighed again after they have been kept in a desiccators over silica gel for $3 \mathrm{hrs}$. . The same procedure was repeated for each temperature.

The corrosion rate and the efficiency were calculated from the loss in weight of the steel samples using the formula ${ }^{(7)}$ :

$$
534 \mathrm{~W}
$$

Corrosion Rate (mpy)=

\section{A T}

Where:

$\mathrm{W}$ : is weight loss (mg).

D: density $\left(\mathrm{g} / \mathrm{cm}^{3}\right)$.

A: area of the carbon steel coupon $\left(\right.$ inch $\left.^{2}\right)$.

$\mathrm{T}$ : exposure time (hour).

The additive percentage inhibition efficiency $(\% \mathrm{E})$ was determined from ${ }^{(8)}$ :

$$
\% \mathrm{E}=\frac{\mathrm{CRo}-\mathrm{CRi}}{\mathrm{CRo}} \times 100
$$

Where:CRo and $\mathrm{CRi}$ are the corrosion rates in the absence and presence of various concentrations of additive respectively. 


\section{Results and Discussion:}

\section{Effect of concentration on corrosion rate \& inhibition efficiency:}

The values of percentage inhibition efficiency (\%IE) and corrosion rate (CR) obtained from weight loss method at different concentrations at $30^{\circ} \mathrm{C}, 40^{\circ} \mathrm{C}$ and $50^{\circ} \mathrm{C}$ are summarized in Table(1).It has been found that vanillin compound inhibits the corrosion of carbon steel in HCI solution, at all concentrations used in this study i.e., $100 \mathrm{ppm}-500 \mathrm{ppm}$. It has also been observed that the corrosion rate decreased with the increase of inhibitor concentration Fig.(1), while the inhibition efficiency of the inhibitor increases with the increase in concentration of inhibitor variation as shown in Fig.(2).

\section{Effect of temperature on inhibition efficiency:}

The variation of IE with solution temperature is shown in Table(1) and Fig.(2). It can be seen that IE increases with increased inhibitor concentration with the maximum inhibition for each temperature at vanillin concentration of 500ppm. The inhibition of corrosion process by vanillin can be attributed to adsorption at the carbon steel - acid solution interface. This usually observed by the decrease in corrosion loss as measured by weight loss (mpy), which depends on the concentration of inhibitor.

Increase in temperature was observed to lower the inhibition efficiency of vanillin and this behavior can be explained on the basis that an increase in temperature resulted in the desorption of some adsorbed vanillin molecules from the steel surface. This makes us predict the mechanism of physiosorption of vanillin on the metal surface. This is in agreement with other studies $^{(9,10)}$.

The inhibiting action of vanillin in HCI solutions can be explained as follows:

The adsorption is assumed to be a quasi - substitution process between the water molecules on the surface and the organic molecules ${ }^{(11,12)}$. The adsorption of vanillin on carbon steel surface would take place through carbonyl, methoxy and hydroxyl groups. This simultaneous adsorption of the three groups forces the vanillin molecule to be horizontally oriented at the metal surface. The area of the surface covered by one molecule is the maximum in case of horizontal orientation of the adsorbed molecules ${ }^{(13)}$. This situation results in high protection efficiency even in case of low inhibitor concentrations. As the inhibitor concentration is increased, the part of the metal surface covered by inhibitor molecule increases leading to an increase in IE.

\section{Kinetics and mechanism of the corrosion inhibition of carbon steel in HCI:}

Table (2) gives the kinetic data obtained in the presence of inhibitor. The rate constants were calculated from the first order rate equation as:

$$
\mathrm{K}=\frac{1}{t} \ln \frac{W i}{W f}
$$

where: $\mathrm{Wi}=$ Initial weight of the coupon, $\mathrm{Wf}=$ Final weight and $\mathrm{t}=$ time in minutes.

The half - life time, $\mathrm{t}_{1 / 2}$ was also calculated from the first order half - life equation:

$\mathrm{t} \frac{1}{2}=\frac{0.693}{k}$

Table (2) gives the kinetic data of the corrosion of carbon steel at different temperatures in the absence and presence of inhibitor.

The activation energy was calculated using the integrated form of the Arrhenius equation below:

$$
\log \frac{k 2}{k 1}=\frac{E a}{2.303 R}\left[\frac{T 2-T 1}{T 1 . T 2}\right]
$$

Where: Ea $=$ Activation energy in $\mathrm{KJ} / \mathrm{mol} . \mathrm{K}=$ the rate constant. $\mathrm{T}=$ Temperature in Kelvin.

The rate constants generally decrease with increased inhibitor concentration at a particular temperature but increased as the temperature increases. Also as the inhibitor concentration increases, the percentage inhibitor efficiencies and the half - life time, $\mathrm{t}_{1 / 2}$ increases for vanillin at a particular temperature but decreases as the temperature increases. 
The average activation energy value of $(57.17 \mathrm{KJ} / \mathrm{mol})$. which is lower than $80 \mathrm{KJ} / \mathrm{mol}$ confirms the physical adsorption mechanism proposed for the inhibition reaction. The increase in the half - life time, $t_{1 / 2}$ when the inhibitor is present as seen in Table (2) shows that vanillin inhibits the corrosion of carbon steel in HCI solution but as the temperature increases, the half - life time, $\mathrm{t}_{1 / 2}$ decreases confirming that vanillin inhibits best at lower temperatures.

Similar trend in kinetic data has been reported by several investigators ${ }^{(14,15)}$ and indicates that a good inhibitor is one that is able to increase the time of conversion of metals to corrosion products ${ }^{(9,16)}$.

\section{Adsorption Consideration:}

The surface coverage $(\theta)$ at each concentration of inhibitor, according to Damaskin ${ }^{(11)}$ was determined using the equation:

$$
\Theta=1-\frac{\mathrm{CRi}}{\mathrm{CRo}}
$$

Where CRo and CRi are the corrosion rates in the absence and presence of inhibitor respectively. They were calculated at various concentrations of the inhibitor. The surface coverage data and corrosion rate are listed in Table(3). The experimentally observed linear decrease in corrosion rate with surface coverage $(\theta)$ supports the observation that the inhibitor inhibits corrosion by being adsorbed at the reaction sites. A curtailment of these reaction sites would therefore, leads to a reduction in the corrosion rate and this may be precisely how the inhibitor molecules achieve inhibition by being adsorbed on the carbon steel surface at the reaction sites. In such a situation, the removal of iron atoms from reaction sites is rendered difficult and needs higher activation energies.

For calculating the entropy $\Delta \mathrm{S}^{*}$ and enthalpy $\Delta \mathrm{H}^{*}$ of activation, the alternative formulation of the Arrhenius equation is the transition state equation ${ }^{(17)}$ :

Wcorr $=\mathrm{RT} / \mathrm{N}$ h $\exp (\Delta \mathrm{S} * / \mathrm{R}) \exp \left(-\Delta \mathrm{H}^{*} / \mathrm{RT}\right)$

Being $\mathrm{h}$ the Planks constant, $\mathrm{N}$ Avogadro's number, $\mathrm{T}$ temperature in Kelvin, and $\mathrm{R}$ gas constant. Fig.(3) shows plots of Log (corr.rate/T) versus 1/T is straight lines with a slope of $\Delta \mathrm{H}^{*}$ $/ \mathrm{R}$ and an intercept of $\{\log (\mathrm{R} / \mathrm{Nh})+\Delta \mathrm{S} / \mathrm{R})\}$. Values of $\Delta \mathrm{H}^{*}$ and $\Delta \mathrm{S}^{*}$ are collected in Table(4). The data showed that the thermodynamic parameters $\left(\Delta \mathrm{H}^{*}\right.$ and $\left.\Delta \mathrm{S}^{*}\right)$ of the dissolution reaction of steel in $0.5 \mathrm{M} \mathrm{HCI}$ in the presence of vanillin are lower than those of the non inhibited solution. The positive values of $\Delta \mathrm{H}$ suggest that the dissolution process is an exothermic phenomenon and that the dissolution of steel is difficult. Also, the entropy $\Delta \mathrm{S}$ in the absence and presence of the inhibitor are large and negative. This indicates that the activated complex in the rate determining step an association rather than a dissociation step, meaning that a decrease in disordering takes place on going from reactants to the activated complex ${ }^{(18)}$.

\begin{tabular}{|c|c|c|c|c|c|c|c|c|}
\hline \multirow[t]{2}{*}{$\begin{array}{c}\text { Inhibitor } \\
\text { concentration } \\
\text { (ppm) }\end{array}$} & \multicolumn{3}{|c|}{$\begin{array}{l}\text { Rate constant } K \\
(\min -1) \times 10-4\end{array}$} & \multicolumn{3}{|c|}{$\begin{array}{c}\text { Half-life, tl/2 } \\
\text { (mins) x } 104\end{array}$} & \multirow[t]{2}{*}{$\begin{array}{c}\text { Activation } \\
\text { energy KJ } \\
\text { mol-1 }\end{array}$} & \multirow{2}{*}{$\begin{array}{c}\text { Average } \\
\text { activation } \\
\text { energy KJ mol-l }\end{array}$} \\
\hline & $303 \mathrm{~K}$ & $318 \mathrm{~K}$ & $323 \mathrm{~K}$ & $303 \mathrm{~K}$ & $318 \mathrm{~K}$ & $323 \mathrm{~K}$ & & \\
\hline 100 & 0.060 & 0.067 & 0.187 & 11.46 & 10.31 & 3.69 & 83.81 & \multirow{5}{*}{$\mathbf{5 7 . 1 7}$} \\
\hline 200 & 0.053 & 0.063 & 0.139 & 12.92 & 9.40 & 495 & 52.40 & \\
\hline 300 & \begin{tabular}{|l|}
0.051 \\
\end{tabular} & 0.061 & 0.129 & 13.52 & 11.18 & 5.35 & 60.20 & \\
\hline 400 & 0.042 & 0.057 & 0.108 & 16.12 & 11.95 & 6.36 & 51.46 & \\
\hline 500 & 0.020 & 0.061 & 0.098 & 33.80 & 11.24 & 7.06 & 37.98 & \\
\hline
\end{tabular}

Table(1): Percent inhibitor efficiency (\% E) and corrosion rate (mpy) of carbon steel in $0.5 \mathrm{M} \mathrm{HCl}$ solution containing various concentration of vanillin at different temperature 
Table( 2): Kinetic data for carbon steel in $0.5 \mathrm{M} \mathrm{HCl}$ containing Vanillin.

\begin{tabular}{|c|c|c|c|c|c|c|c|c|}
\hline \multirow[t]{2}{*}{$\begin{array}{c}\text { Inhibitor } \\
\text { concentration } \\
\text { (ppm) }\end{array}$} & \multicolumn{3}{|c|}{$\begin{array}{l}\text { Rate constant } K \\
\text { (min-1) } \times 10-4\end{array}$} & \multicolumn{3}{|c|}{$\begin{array}{c}\text { Half-life, tl/2 } \\
\text { (mins) x } 104\end{array}$} & \multirow[t]{2}{*}{$\begin{array}{c}\text { Activation } \\
\text { energy KJ } \\
\text { mol-1 }\end{array}$} & \multirow{2}{*}{$\begin{array}{l}\text { Average } \\
\text { activatio } \\
\text { n energy } \\
\text { KJ moll }\end{array}$} \\
\hline & \begin{tabular}{|l}
$303 K$ \\
\end{tabular} & $318 \mathrm{~K}$ & $323 \mathrm{~K}$ & $303 \mathrm{~K}$ & $318 \mathrm{~K}$ & $323 \mathrm{~K}$ & & \\
\hline 100 & 0.060 & 0.067 & 0.187 & 1146 & 1031 & 3.69 & 8381 & \multirow{5}{*}{5717} \\
\hline 200 & 0.053 & 0.063 & 0.139 & 1292 & 9.40 & 495 & 5240 & \\
\hline 300 & 0.051 & 0.061 & 0.129 & 1352 & 11.18 & 535 & 6020 & \\
\hline 400 & 0.042 & 0.057 & 0.108 & 16.12 & 1195 & 636 & 5146 & \\
\hline 500 & 0.020 & 0.061 & 0.098 & 3380 & 1124 & 7.06 & 3798 & \\
\hline
\end{tabular}

Table (3): Effect of Inhibitor concentration and Temperature on the corrosion rate (mpy) and surface coverage $(\theta)$ for the carbon steel in $0.5 \mathrm{M} \mathrm{HCl}$.

\begin{tabular}{|c|c|c|c|c|c|c|}
\hline \multirow{3}{*}{ Conc. (ppm) } & \multicolumn{6}{|c|}{ Temperature (K) } \\
\hline & \multicolumn{2}{|c|}{303} & \multicolumn{2}{|c|}{313} & \multicolumn{2}{|c|}{323} \\
\hline & mpy & $\boldsymbol{\theta}$ & mpy & $\boldsymbol{\theta}$ & mpy & $\boldsymbol{\theta}$ \\
\hline 100 & 145.63 & 0.56 & 184.39 & 0.60 & 465.09 & 0.28 \\
\hline 200 & 137.41 & 0.58 & 183.21 & 0.60 & 360.56 & 0.44 \\
\hline 300 & 131.54 & 0.60 & 167.95 & 0.63 & 325.33 & 0.49 \\
\hline 400 & 103.35 & 0.68 & 157.38 & 0.66 & 294.79 & 0.54 \\
\hline 500 & 56.37 & 0.82 & 155.03 & 0.66 & 251.33 & 0.61 \\
\hline
\end{tabular}

Table (4): Activation parameters of carbon steel in 0.5 M HCL with and without Vanillin.

\begin{tabular}{||c||c||c||}
\hline $\begin{array}{c}\text { Inhibitors } \\
\text { conc.(ppm) }\end{array}$ & $\Delta \mathrm{H}(\mathrm{KJ}$ mol-1) & $-\Delta \mathrm{S}(\mathrm{J}$ mol/K-1) \\
\hline \hline Blank & 57.44 & 22.43 \\
\hline 100 & 21.06 & 29.98 \\
\hline 200 & 15.31 & 28.06 \\
\hline 300 & 11.67 & 26.78 \\
\hline 400 & 11.67 & 26.94 \\
\hline 500 & 12.36 & 27.45 \\
\hline
\end{tabular}




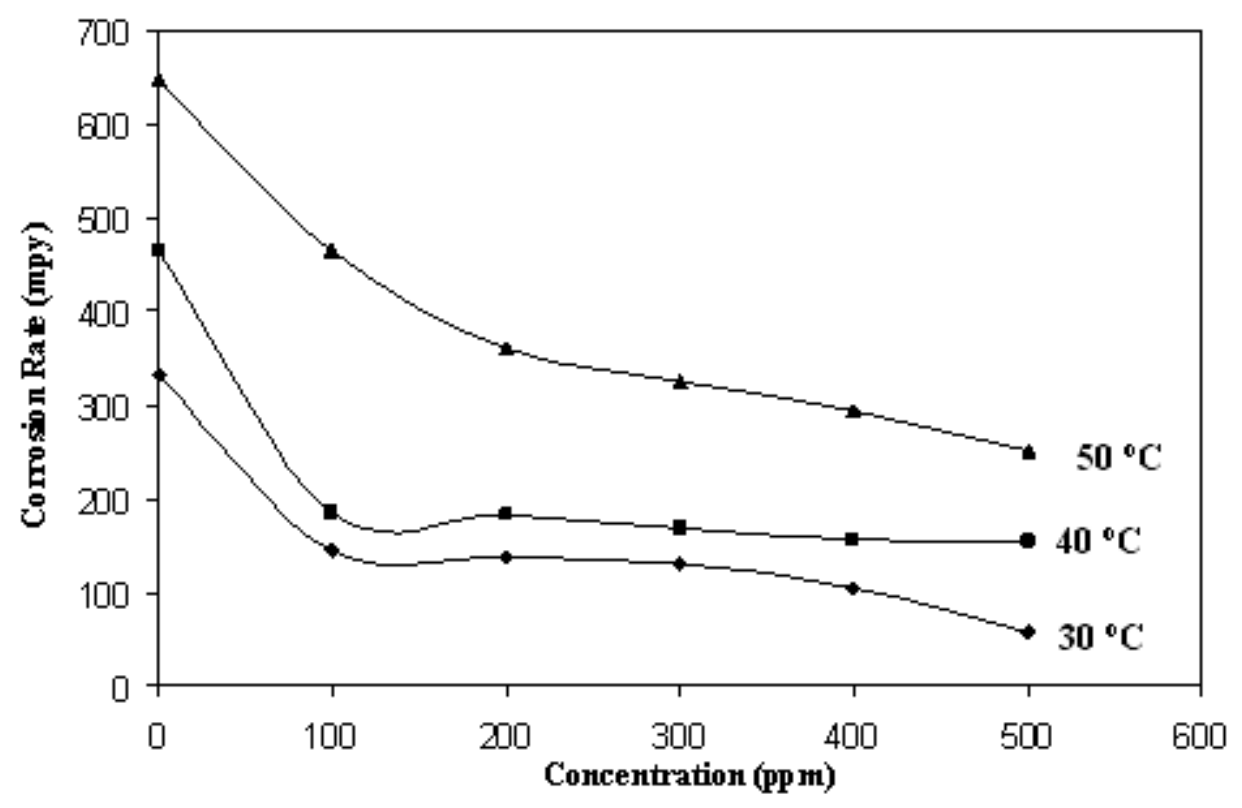

Figure (1): Variation of corrosion rate with various concentration of Vanillin for carbon steel in $0.5 \mathrm{M} \mathrm{HCl}$ solutions at $30^{\circ} \mathrm{C}, 40^{\circ} \mathrm{C}$ and $50^{\circ} \mathrm{C}$.

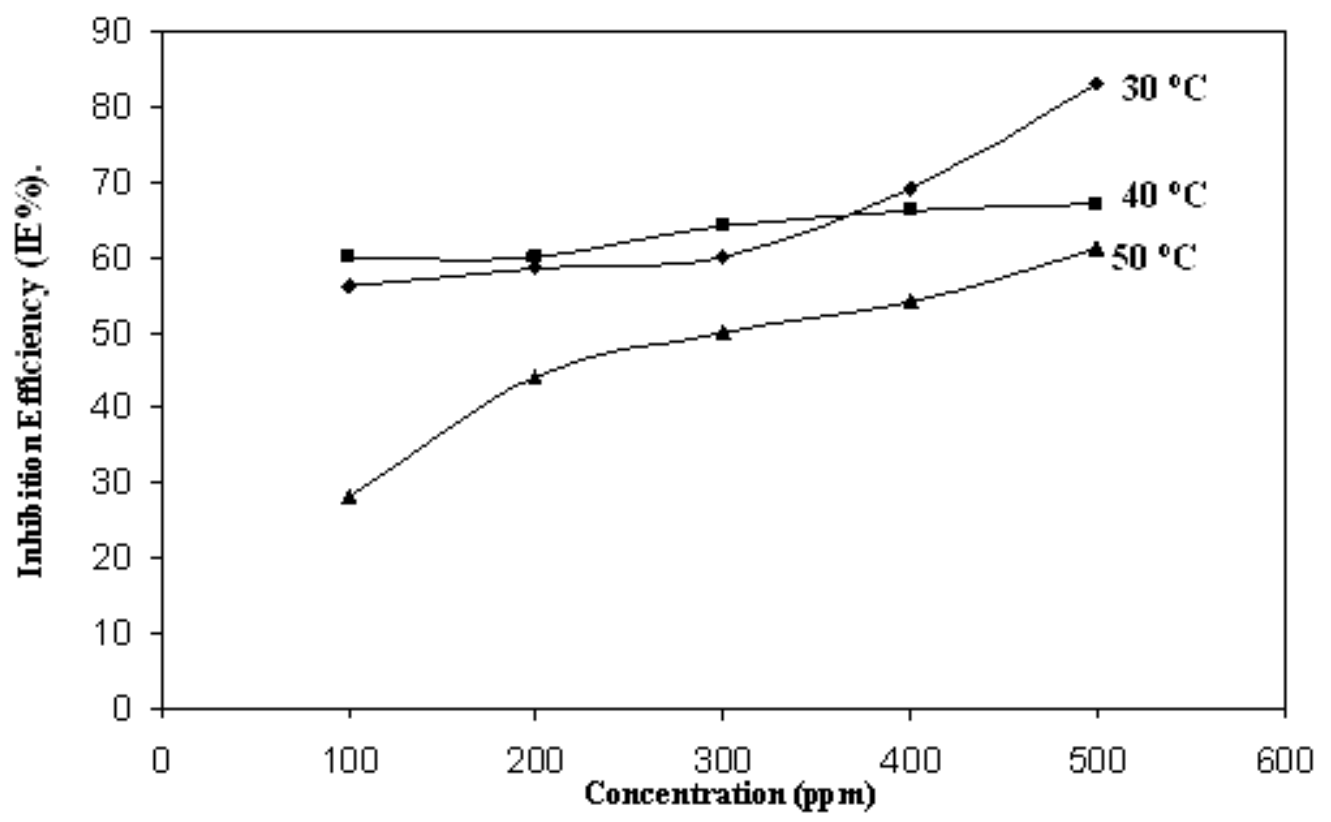

Figure (2): Variation of percentage Inhibition efficiency with various concentration of Vanillin for carbon steel in $0.5 \mathrm{M} \mathrm{HCl}$ solutions at $30^{\circ} \mathrm{C}, 40^{\circ} \mathrm{C}$ and $50^{\circ} \mathrm{C}$. 


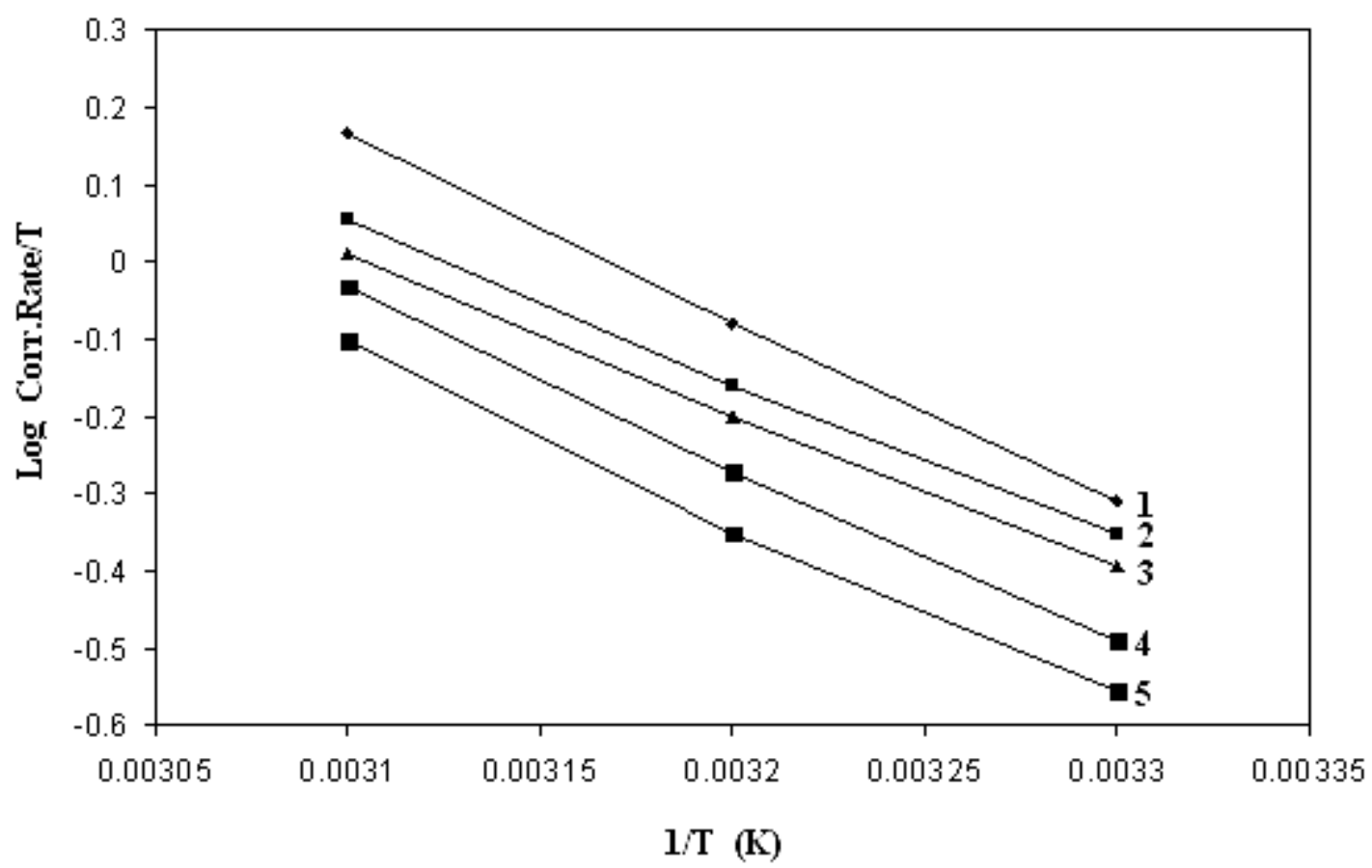

Figure(3):Plot of $\log (\mathrm{Corr}$.Rate/T) against 1/T for carbon steel in 0.5M HCL at different concentrations of Vanillin:(1)100ppm, (2)200ppm, (3)300ppm, (4)400ppm and (5)500ppm.

\section{References:}

1.G. Vasudha \& R.Saratha, J.of Corro.Sci. and Engin., 10, (2007).

2- G.Schmitt, British Corro.J.,19, (1984).

3- B.A. Abd-El-Nabi, E. Khamis, M.S. Ramadan \& A.El-Gindy, Corrosion, 52, (1996).

4- A.Raman \& P.Labine, Reviews on Corro. Inhib. Sci. Tech., NACE, International Houston, 2, 1, (1996).

5- S.M. Hassan, M.N.H. Moussa, F.I.M. Taha, \& A.S. Fouda, Corro. Sci., 21, (1981).

6- Mathur P.B.\& Vasudevam, 38, (1982).

7- R.S. Tredder, NACE, Houston, Texas, 7,(1984).

8- M.J.Danielson, J.Corro., (NACE), 11, (1982).

9- Abiola O.K. \& Oforka N.C., Corrosion Sci. \& Engin., 3, (2002).

10- Olusegun K.A. \& Oforka N.C., Corrosion Sci.\& Engin., 7, (2004).

11- Damaskin B.B. \& Frumkin A.N., "Reactions of molecules at electrodes", Ed. N.S.Hush (Wiley interscience, London), (1971).

12- Fouda A.S., Madkour L.H., El-Shafel A.A. \& Abd El-Maksoud S.A., Bull. Korean Chem. Soc., 16, (1995).

13- A.Y.El-Etre, Corrosion Sci., 43, (2001).

14- E.E.Ebenso, J.Nig.Corr., 1,(1998).

15- E.E.Ebenso, P.C.okafor, O.E.Offiong, B.I.Ita, U.J.Ibok, \& U.J.Ekpe, Bull. Electrochem., 17, (2001).

16- A.O.James, N.C.Oforka, O.K.Abiola, J. of Corr. Sci. and Eng. , 7, (2005).

17- M.Bouklah \& B.Hammouti, Port. Electrochimica Acta, 24, (2006).

18- M.A.Qurraishi, M.Z.A.Rafiquee, N.Saxena \& S.Khan, J. of Corr. Sci. and Eng. , 10, (2006). 
تثبيط التآكل للفولاذ الكاربوني في الوسط الحامضي باستخدام الفانيلين

عـدنان سلطان عبد النبي لمى طاهر طعمه إحسان عاثشور مكثف

قسم الكيمياء - كلية التربية - جامعة البصرة

\section{الخلاصة}

درس الفعل التثيطي لنآكل الفو لاذ الكاربوني في حامض الهيدروكلوريك باستخدام الفانيلين وباستخدام طريقة الفقدان بالوزن. وقد وجد بأن كفاءة التثبيط تزداد مع ازدياد تركيز المثبط ونقصان درجة الحرارة. كما أظهرت النتائج الحركية التي تم حسابها لطريقة الفقدان بالوزن بان عملية التثبيط هي من نوع الأمدصاص الفيزيائي. كنلك بينت النتائج إمكانية استخدام الفانيلين كمانع تآكل فعال التقليل تآكل الفو لاذ الكاربوني في وسط حامضي. 